\title{
A REPORT ON THE VENTILATION OF SCHOOLS
}

\author{
By J. V. A. SIMPSON, M.D. (Lond.), D.P.H. (Самв.).
}

(With 1 Graph.)

"HEALTH is more affected by atmospheric conditions than by any other influence. From the moment the new born child utters its first cry, until life finally ceases, he is directly and immediately dependent on the atmosphere he breathes for continued existence. Records of sickness and of mortality clearly show that the nearer atmospheric conditions are to those of the open country, the better is the health of the population, and that the more these conditions are modified owing to urbanisation and industrialisation, the more pronounced is the ill-effect upon general health" (1).

The vast importance and the far-reaching effects of this statement are at present only partially realised, and reluctantly admitted, but each year the medical statistician brings forward accurate and uniform findings, the significant deductions from which it is imperative to consider and utilise. Recent work on the epidemiology of phthisis by Collis and Greenwood(1) has shown that the factory, by confinement of the workers in monotonously ventilated rooms, and by causing general fatigue, reduces the resistance of the operative to those sources of infection to which he is exposed at home. These authors maintain that, in the light of this, "it is not through any special intensive measures of campaigning against the tubercle bacillus, not even by the segregation of the actively tuberculous does there seem any real hope of salvation." But rather the ideal is to improve the conditions of the home and the factory.

Furthermore, Leonard Hill(2) has shown that there is a considerable correlation between variations not only of the sense of well-being, but of actual prevalence of sickness, and the degree of stagnation of the air; and the whole group of respiratory affections ("colds," catarrhs, sore throats, bronchitis, penumonia, measles, cerebro-spinal fever, and whooping cough) are in their spread largely influenced by the moist heated atmospheres of indoor life.

This being the case, it is self-evident that the adequate ventilation, and efficient general hygiene of the home, factory, and school (for the school in child life corresponds to the factory of the adult) are most powerful influences in the prevention of disease. And, because prevention is surely the best economy, these measures must not be unwillingly considered, inadequately taken up or totally rejected. As Sir George Newman writes, "The Public Health is not only a matter of the postponement of mortality and the prevention of sickness, but of the positive side of health-the increase of vitality, capacity and efficiency of the human body....To secure this end, we must pay attention not only to actual ailments and diseases, but to the conditions making for a 
maximum degree of personal health." And, surely, one of the most important of these conditions in the case of the child is the Hygiene of the School-room.

In the present report, the ventilation of four schools has been investigated: Schools A, B, C and D. The first two were taken as examples of the Plenum System; School C, a one-storey building of recent design (1913) was chosen to represent the most favourable conditions likely to be found in any elementary school with natural ventilation; and School D (built 1873) was the example of an older building without mechanical ventilation.

The methods of investigation are:

(1) $\mathrm{CO}_{2}$ estimation.

(2) Readings of the kata-thermometer.

(3) Relative number of organisms present.

(4) Incidence of disease.

(5) Personal test.

The reason for using each method, and the relative importance of the results will be dealt with under each heading; but it is convenient to mention, at this juncture, that owing to lack of time, some of the results obtained are inadequate in number. This is especially the case with the estimations of $\mathrm{CO}_{2}$ and of the bacteria present in the air: but less time was purposely spent in these estimations, for, as will be seen, there is not very much importance attached to these results now, and consequently the general conclusions are not affected.

\section{(1) $\mathrm{CO}_{2}$ Estimation.}

The $\mathrm{CO}_{2}$ present in the air was estimated by Pettenkofer's method, and the results are set out in Table 1 (at the end of this report). It will be seen that the schools with natural ventilation give approximately the same results as those where the Plenum system is in use.

Originally, attention was directed towards the gaseous condition of the atmosphere, and the air was deemed bad or good according as the proportion of $\mathrm{CO}_{2}$ was more or less than a certain arbitrary standard-such as $0 \cdot 1$ per cent. (Pettenkofer), 0.13 per cent. (Carnelly, Anderson and Haldane). The advocates of such standards had to modify their views when it was demonstrated that air with large amounts of $\mathrm{CO}_{2}$, amounts such as are never met with under ordinary conditions (e.g. 150 to 300 times the amount present in pure air) produced no ill-effects when breathed. It was then claimed that $\mathrm{CO}_{2}$ was a useful measure of the poisonous emanations and respiratory impurities, but careful investigation has failed to establish the existence of such qualities.

The most recent view is that the chemical composition of occupied rooms is adequate for all the needs of respiration and that ill-effects are not dependent upon the balance of oxygen and carbon dioxide present. Therefore, not much attention is paid in this report to the results of $\mathrm{CO}_{2}$ estimation. As Collis and Greenwood(1) say: "The fetish of a low $\mathrm{CO}_{2}$ content must be replaced by the sound doctrine-long enough known instinctively to the people-that moving air, not a draught, but a breeze is health-giving." 
(2) Kata-Thermometer Readings.

Leonard Hill(2) says, "the evaporative power of the atmosphere has a far-reaching effect not only on the comfort of the skin, but on the respiratory mechanism, the absorption of water from the gut and the renal secretion. The ceaseless variations in the rate of cooling, evaporation, absorption of radiant energy, as in outdoor conditions, relieves us from monotony, stimulates tone and metabolism." In pressing this point of view he urges that the whole question of ventilation depends not upon the supposed presence of injurious chemical products, but on movement of air of suitable temperature and humidity.

To the subject of the amount of movement required, Leonard Hill has devoted much research: he has designed an instrument to measure comparatively and approximately the rate of heat loss of the body under varying conditions. This instrument is the Kata-Thermometer (down-heat-measure): it is a large bulbed spirit thermometer with a safety bulb at the top. In use, the bulb is dipped into hot water until the alcohol rises into the safety bulb, and then the instrument is dried and suspended in the air to be tested: the time taken to fall from $100^{\circ}$ to $95^{\circ} \mathrm{Fahr}$. $\left(2 \frac{1}{2}^{\circ}\right.$ above and below normal body temperature) is measured with a stop watch. The instrument is then used wet, i.e. with a silk mesh finger stall placed over the bulb, the excess water shaken off and the readings taken. Several readings (three or four) should be registered with each and the average worked out.

The dry bulb gives the cooling power by radiation and convection, the wet by radiation, convection and evaporation: to find this, each instrument possesses a factor (which has been evolved under specific conditions) and into this factor is divided the number of seconds which has been found by the experiment in question. This gives the cooling power in milli-calories per square centimetre per second: and the standards which Hill lays down as absolute minima are:

For dry kata the reading should not be less than 6 .

For wet kata the reading should not be less than 18 .

Preferably in schools, the dry reading should be over 7 and the wet over 20 , because children, having a greater metabolism per unit of body surface than adults, need an atmosphere with not less, but a greater cooling power.

The results obtained in the four schools are shown in Table 2, and the readings are plotted in Graph $\mathrm{I}$. It will be seen that Schools $\mathrm{C}$ and $\mathrm{D}$ show uniformly good readings: on only two occasions does the wet reading fall below 18, and this was caused by the windows in the particular rooms not being properly controlled. By altering the windows, the readings were brought above the minimum. In many of the experiments it will be noticed that the results for the dry kata were over 7 and for the wet exceeded 19, so that they nearly conformed to Hill's more stringent standard for schools. This is perhaps to be expected at School C, for that is a model building, situated in a very 
J. V. A. Simpson

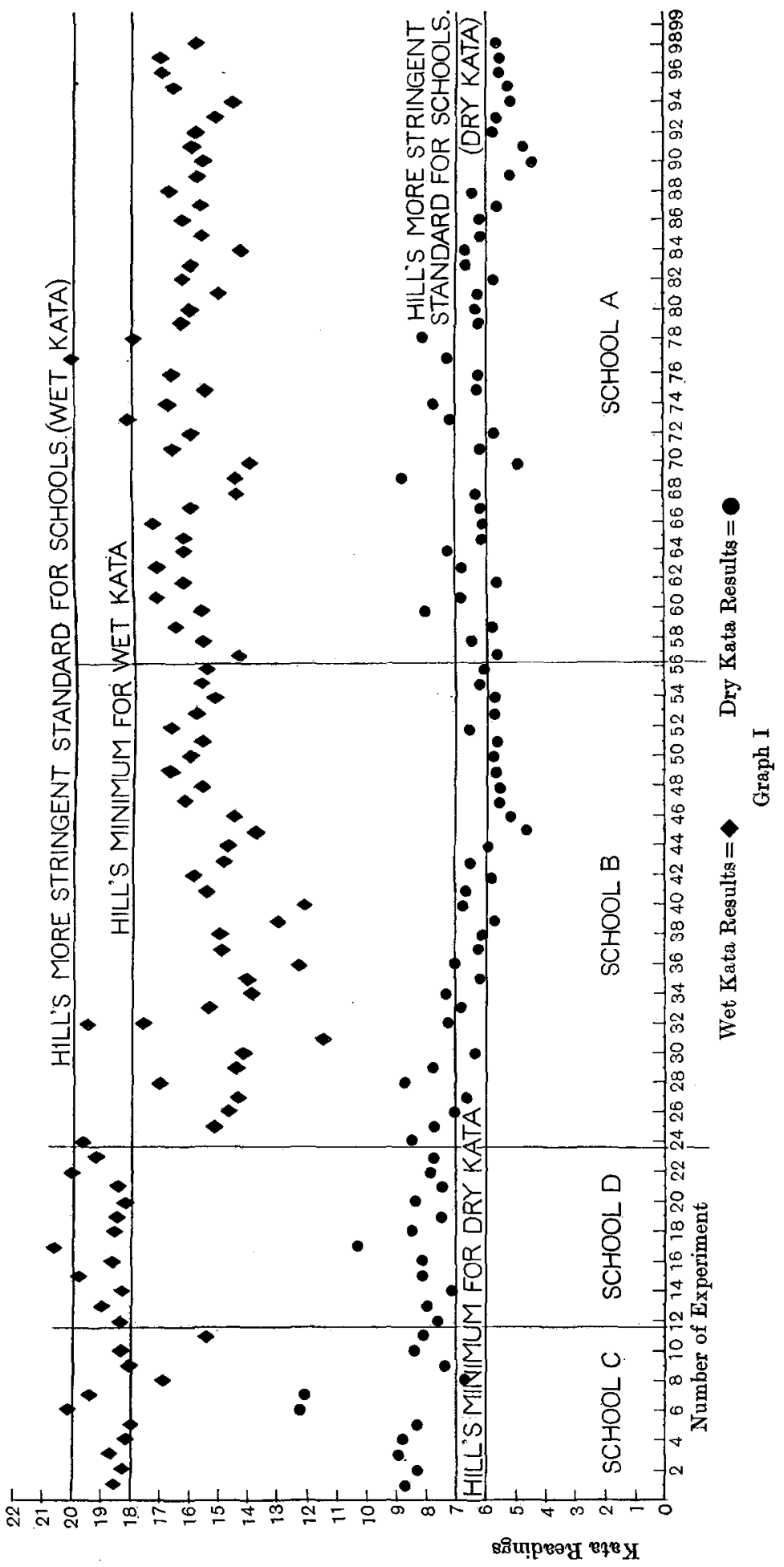


favourable open position on the outskirts of the city: but it is indeed gratifying to find such results at School D, which is situated in the centre of the city, in one of the poorer districts, surrounded and enclosed by buildings on all sides.

On the contrary, the two schools with mechanical ventilation give far less favourable results: both at School $A$ and School $B$ it is the exception to find the wet reading over 18 , and on many occasions the dry reading was below 6 -in one experiment as low as $4 \cdot 5$. Moreover, it must be admitted that during the time these experiments were carried out, the wind was uniformly north-easterly, and the ventilation appeared from personal tests better than is the case in the more usual "muggy" type of English weather. Experiments 90-98 inclusive were taken on such a "muggy" day and show less favourable results: and further experiments will be carried out to ascertain if this difference is correct. On those occasions where the readings were above the minima laid down by Hill, there is a definite reason, and attention is drawn particularly to experiment 77 where readings of $7 \cdot 3$ for dry kata and $20 \cdot 1$ for wet kata were obtained, because the teacher, who stated that the children were falling asleep owing to the oppressive atmosphere, had opened the windows about ten minutes before the experiment was taken. The rooms next to it (experiments 75 and 76) had readings much lower, and these rooms had no windows open.

It may be objected that opening certain windows vitiates the working of the system, and that consequently certain experiments are not a true test: therefore, to meet this criticism, experiments 44--56 inclusive were carried out with the system working as its designers planned, all windows being closed. The results are uniformly worse than are obtained under the conditions which the teachers bring about by opening a few windows.

To show the importance of movement in the air so far as kata readings are concerned, experiments 29 and 32 may be cited: in the former, the wet kata reading was 14.5 with the class sitting still and 15.8 with the children waving their arms. Similarly in experiment 32 , the reading was 19.5 when the girls were dancing, and only 17.6 when no dancing was in progress.

With the dry kata-thermometer, it is possible to measure the velocity of the air, and experiments were carried out to ascertain the velocity of the air as it entered the rooms from the shafts. The results are recorded in Table 3: it will be seen that even on the same day, the variations in the velocity had no definite relationship to the kata readings. Presumably, then, the velocity of the incoming air is never sufficient, as a general rule, to give such necessary movement as will allow good kata results.

\section{(3) Organisms.}

The air of occupied rooms is known to contain bacteria, the number of which vary according to the degree of cleanliness and the amount of ventilation. All organisms are not pathogenic, and the estimation of the number present at any time is no certain indication of danger arising from infection. 


\section{J. V. A. Simpson}

Therefore not much importance is attached to this method of investigation. These experiments, recorded in Table 4, were carried out under conditions approximately the same (for merely marching the children out of the room would increase considerably the number of organisms falling per unit area), and it will be seen that the average for the two different types of school is approximately the same.

\section{(4) The Incidence of Disease.}

Of very great importance is the comparative incidence of infectious disease, because it may be taken to show, in a definite way, the effects of different methods of ventilation. Unfortunately, it has been impossible in the schools under consideration to obtain any conclusive figures, but the general opinion of those who have worked for considerable periods in both types of school is that the sickness rate among staff and pupils alike is decidedly higher in the Plenum school. This is certainly in keeping with other observations, and the following illustrations of the importance of ventilation on the spread of disease may be cited.

"We find that the window-ventilated room at $67^{\circ} \mathrm{Fahr}$. is characterised by materially lower incidence of respiratory disease than the fan-ventilated room at $69^{\circ} \mathrm{Fahr}$.... The window-ventilated room is somewhat more comfortable" (9).

Fan-ventilated rooms showed 18 per cent. more absences due to respiratory illness and 70 per cent. more respiratory illness among children in attendance, in spite of the fact that per capita floor space was greater in these than in the window-ventilated (9).

In an Australian troopship, three decks were well, and the fourth badly ventilated: the incidence of infective pharyngitis and epidemic catarrh was ten times greater among the troops on the badly ventilated deck (3).

Again, in 1914-15, the Canadian troops were camped in tents on Salisbury Plain under extreme conditions of wet and discomfort, but with excellent health. As soon as they moved into huts, catarrhs and sore throats spread rapidly, and several cases of cerebro-spinal fever occurred (2).

(5) The Personal Test.

A. T. Nankivell, after a long series of experiments from May to December, 1915, in the four camps of the Dorset Training Area, found that the personal test was the best guide in ventilation, and quite as reliable as any of the orthodox chemical standards. Parkes and Kenwood(4) maintain that the sense impression of the state of the atmosphere "is probably one of the most reliable guides in judging the conditions of the atmosphere. It is the summing up by the individual's senses of everything that makes for the production of unhealthy conditions, whether this be temperature, excessive moisture or lack of movement in the air."

Certainly, the Plenum schools give an unpleasant sensation on entering the building, and the feelings of drowsiness, inertia and lassitude persist: 
it is therefore not surprising that those who work in such schools should complain of the marked discomfort of the ventilation.

\section{General Conclusions.}

The general conclusions reached, then, seem to indicate decisively that the mechanical systems of ventilation, as they are worked in Schools A and B, are definitely unsatisfactory: excluding the considerations of the personal tests (for in that the individual may be alleged to be biased) the bare scientific results detailed above show that no other conclusion can legitimately be given.

It is easy to criticise adversely and to find fault, but it is vastly more difficult to formulate a balanced constructive criticism; and in attempting to find a solution, even a palliative remedy for the defects now patent, it is convenient to consider the ideals of ventilation. The desiderata are:

(a) "Cool rather than hot."

(b) "Dry rather than damp."

(c) "Diverse in temperature in different parts and at different times rather than uniform and monotonous," and

(d) "Moving rather than still" (5).

Or again, "Successful ventilation depends on the prevention of stagnation of the body heat on the one hand, and uncomfortable chilling of the body on the other. Not only should it prevent heat stagnation in schools and workshops, but it should stimulate the worker" $(6)$.

\section{Recommendations.}

Palliative measures to improve the present systems at these schools include:

(1) Installation of fans for extraction and for remedying the stagnation of the air; and these fans must be so placed in relation to the Plenum inlets as to ensure complete ventilation of the room with suitable air movement at the working places. In addition, if desired, localised air circulation may be obtained by flat paddles or wafters. The construction and installation of any of these should be controlled experimentally by kata-thermometer readings, and one or two installed as a trial rather than the whole number fitted in immediately. For details of types of fans, optimum places in which to place them, and other particulars, it is very desirable to refer to the useful information in the Home Office Publication on the Ventilation of Factories and Workshops (7).

"The effect of a fan put to stir the air in a factory is shown by the following:

$\begin{array}{ccl}\text { Dry kata } & \text { Wet kata } & \\ 4 \cdot 0 & 15 \cdot 0 & \text { Fan off } \\ 6 \cdot 0 & 25 \cdot 5 & \text { Fan on "(6). }\end{array}$

(2) Intervals of work. During play-time, and after school, the air of the rooms could be greatly improved by throwing all windows and doors open and obtaining a through draught for a few minutes. As at present used, the Plenum system is only worked from about 8 a.m. to 4 p.m., Monday to Friday in- 
clusive each week, and thus every evening from 4 p.m. (although evening classes are held in these schools) until the next morning, and all day on Saturday and Sunday, the air is unchanged and complete stagnation results. By opening windows even for a few minutes, much can be done, as is shown in the case of a cinema theatre where, by opening all doors in an interval, the $\mathrm{CO}_{2}$ sank from 44 to $17 \frac{1}{2}$ parts per $10,000(6)$. At school during play-time and after school hours, the monitors in each class could be made responsible for opening and shutting all windows, and the head teachers agree that this could be done. Careful supervision, however, would have to be used, because in some schools the infants go out to play at different times from the older children, and this might create a difficulty; but it would not be of great importance if the whole Plenum system was put out of action for the duration of the combined playtime. As the Building Regulations for Elementary Schools lay down, "Adequate means for ventilating all rooms used for teaching must be provided, not only for admitting fresh air during use, but for flushing the rooms effectually during the intervals" (8).

Finally, the all-importance of ventilation must again be urged, for "health is more affected by atmospheric conditions than by any other influence" $(1)$ : as Hill(2) writes of the evils resulting from the indoor life under which conditions the majority of people are compelled to exist:

"Cramming in close rooms for competitive examinations makes pale weaklings of growing boys and girls. The confined life in office and workshop destroys good looks, weakens strength, lessens happiness and shortens life.... The streets of our cities are trod by hosts of men and women ugly of complexion, ill-grown, weaklings, withered and worn, incapable of strenuous muscular action at a time which should be their prime, developed in cunning, fear and sensitivity to pain by a mean struggle for existence in mean streets."

Preventive Medicine must strive continuously and vigorously to remove this terrible indictment, and so far as the School Medical Service is concerned, must hold high the ideal one day to be achieved: when the conditions of the school will materially help the child to grow strong enough to know something of the "joie de vivre," and when the conditions of the class-room will enable the teacher to understand the unfathomable wisdom of the philosophy that to all men "Labour is the joyful business of life."

\section{REFERENCES.}

(1) Collis, E. L. and Greenwood, M. (1921). The Health of the Industrial Worker.

(2) HILL, L. (1919). The Science of Ventilation and Open Air Treatment, Part 1. Medical Research Committee, Special Report Series, No. 32.

(3) (1919). Brit. Med. Journ. I. 257.

(4) Parkes, L. and Kenwood, H. R. (1920). Hygiene and Public Health.

(5) (1916). Ventilation and Lighting in Munition Factories, Memo. No. 9, Cd. 8215.

(6) (1920). The Science of Ventilation and Open Air Treatment, Part 2. Medical Research Committee, Special Report Series, No. 52.

(7) (1920). Ventilation of Factories and Workshops, Home Office.

(8) (1922). Building Regulations for Public Elementary Schools. Board of Education, Cd. 7516.

(9) (1923). Report of the New York State Commission on Ventilation. 
Table 1.

Estimation of $\mathrm{CO}_{2}$ (Pettenkofer's method).

\begin{tabular}{|c|c|c|c|c|c|c|c|c|c|}
\hline Sehool & Date & Time & Room & $\begin{array}{c}\text { No. of } \\
\text { children }\end{array}$ & $\begin{array}{l}\text { Artificial light } \\
\text { or other } \\
\text { contamination }\end{array}$ & $\begin{array}{l}\text { Temp. } \\
\text { oFahr. }\end{array}$ & $\% \mathrm{CO}_{2}$ & $\begin{array}{l}\text { Dry } \\
\text { kata }\end{array}$ & $\begin{array}{l}\text { Wet } \\
\text { kata }\end{array}$ \\
\hline B & 21. ii. 23 & $4 \cdot 0$ & 3 & 32 & $\mathrm{Nil}$ & 62 & $0 \cdot 104$ & $6 \cdot 7$ & 14.4 \\
\hline , & 22. ii. 23 & 3.50 & 7 & 36 & 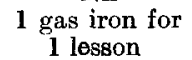 & 62 & $0 \cdot 135$ & * & 11.5 \\
\hline 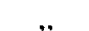 & 23. ii. 23 & 3.40 & 5 & 40 & Nil & 63 & 0.118 & $6 \cdot 9$ & $15 \cdot 4$ \\
\hline 30 & 26. ii. 23 & 11.0 & 5 & 40 & , & 62 & 0.074 & $6 \cdot 1$ & $15 \cdot 1$ \\
\hline $\mathrm{C}$ & 27. ii. 23 & 4.0 & A & 40 & " & 62 & $0 \cdot 103$ & $8 \cdot 7$ & $18 \cdot 6$ \\
\hline ," & 28. ii. 23 & 11.0 & $\mathrm{~A}$ & 40 & " & 58 & 0.074 & $8 \cdot 8$ & $18 \cdot 1$ \\
\hline ", & 28. ii. 23 & 2.30 & B & 44 & , & 59 & $0 \cdot 114$ & * & * \\
\hline , & 28. ii. 23 & 3.45 & $\mathrm{H}$ & 40 & " & 65 & 0.165 & $8 \cdot 3$ & $18 \cdot 0$ \\
\hline & 1. iii. 23 & 11.0 & F & 34 & $"$ & 65 & 0.167 & $6 \cdot 7$ & $16 \cdot 9$ \\
\hline A & 2. iii. 23 & 2.30 & 2 & 37 & , & 66 & 0.139 & $6 \cdot 5$ & $15 \cdot 7$ \\
\hline , & 2. iii. 23 & 3.45 & 5 & 45 & , & 66 & 0.136 & $5 \cdot 9$ & $16 \cdot 6$ \\
\hline ," & 7. iii. 23 & 2.10 & 4 & 48 & , & 68 & $0 \cdot 134$ & $6 \cdot 2$ & $16 \cdot 3$ \\
\hline , & 7. iii. 23 & 3.40 & 6 & 44 & ," & 65 & $0 \cdot 135$ & * & * \\
\hline
\end{tabular}

* Reading not taken.

Average $\mathrm{CO}_{2}$ for School B, 0.12\%; School C, 0.12\%; School A, 0.14\%.

Kata readings are shown in order to demonstrate complete absence of any relationship between $\mathrm{CO}_{2}$ content and good or bad kata readings.

Table 2.

Kata-Thermometer readings.

\begin{tabular}{|c|c|c|c|c|c|c|c|c|c|}
\hline $\begin{array}{l}\text { No. of } \\
\text { Exp. } \\
\text { (1) }\end{array}$ & $\begin{array}{l}\text { School } \\
(2)\end{array}$ & $\begin{array}{c}\text { Date } \\
(3)\end{array}$ & $\begin{array}{c}\text { Time } \\
\text { (approx.) } \\
(4)\end{array}$ & $\begin{array}{l}\text { Room } \\
\text { (5) }\end{array}$ & $\begin{array}{l}\text { No. of } \\
\text { children } \\
(6)\end{array}$ & $\begin{array}{l}\text { Temp. } \\
\text { Fahr. } \\
(7)\end{array}$ & $\begin{array}{l}\text { Dry } \\
\text { kata } \\
(8)\end{array}$ & $\begin{array}{l}\text { Wet } \\
\text { kata } \\
(9)\end{array}$ & $\begin{array}{l}\text { Remarks } \\
\text { (10) }\end{array}$ \\
\hline 1 & $\mathrm{C}$ & 27. ii. 23 & 4.0 p.m. & A & 40 & 62 & $8 \cdot 7$ & $18 \cdot 6$ & \\
\hline 2 &, & , & 4.15 & B & 45 & 64 & $8 \cdot 3$ & $18 \cdot 3$ & \\
\hline 3 & , & , & 4.30 & Hall & - & 58 & 8.9 & $18 \cdot 7$ & \\
\hline 4 & ", & 28. i. 23 & 11.0 a.m & A & 40 & 58 & $8 \cdot 8$ & $18 \cdot 1$ & \\
\hline 5 & ," & , & 3.45 p.m. & $\mathrm{H}$ & 40 & 65 & $8 \cdot 3$ & 18.0 & \\
\hline 6 & , & , & 4.0 & $\mathrm{~F}$ & 36 & 58 & $12 \cdot 2$ & $20 \cdot 1$ & \\
\hline 7 & ", & ", & 4.15 & $\mathbf{E}$ & 36 & 61 & $12 \cdot 1$ & $19 \cdot 4$ & \\
\hline 8 & , & 1. iji. 23 & 11.0 a.m. & $\vec{F}$ & 34 & 65 & $6 \cdot 7$ & 16.9 & \\
\hline 9 & ", & , & 11.30 & $\mathbf{D}$ & 35 & 63 & $7 \cdot 4$ & $18 \cdot 1$ & \\
\hline 10 & , & , & 11.40 & $\bar{G}$ & 40 & 63 & $8 \cdot 4$ & $18 \cdot 3$ & \\
\hline 11 & ," & ," & 11.55 & I & 34 & 65 & $8 \cdot 1$ & $15 \cdot 4$ & \\
\hline 12 & $\mathrm{D}$ & 16. iii. 23 & 2.35 p.m. & B & 24 & 61 & $7 \cdot 6$ & $18 \cdot 4$ & \\
\hline 13 & , & ", & 2.45 & $\mathrm{C}$ & 22 & 62 & $8 \cdot 0$ & $19 \cdot 0$ & \\
\hline 14 & ," & ", & 2.55 & D & 35 & 65 & $7 \cdot 1$ & $18 \cdot 3$ & \\
\hline 15 & $"$ & , & $3 \cdot 50$ & A & 40 & 61 & $8 \cdot 1$ & $19 \cdot 8$ & \\
\hline 16 & , & , & 3.15 & $\mathbf{E}$ & 35 & 56 & $8 \cdot 1$ & $18 \cdot 6$ & \\
\hline 17 & , & , & 3.35 & $\mathrm{~F}$ & 44 & 56 & $10 \cdot 3$ & $20 \cdot 6$ & \\
\hline 18 & , & 20. iii. 23 & 3.40 & B & 24 & 61 & $8 \cdot 5$ & $18 \cdot 6$ & \\
\hline 19 & ," & , & 2.45 & C & 22 & 63 & $7 \cdot 5$ & $18 \cdot 5$ & \\
\hline 20 & $"$ & , & 2.55 & $\mathrm{D}$ & 35 & 62 & 8.4 & $18 \cdot 2$ & \\
\hline 21 & , & , & 3.5 & A & 40 & 62 & $7 \cdot 5$ & $18 \cdot 4$ & \\
\hline 22 & , & , & 3.20 & $\mathrm{E}$ & 35 & 64 & 7.9 & $20 \cdot 1$ & \\
\hline 23 & ," & ", & 3.30 & $\bar{F}$ & 44 & 66 & $7 \cdot 8$ & $19 . \overline{2}$ & \\
\hline 24 & B & 21. ii. 23 & 3.45 & Hall & - & 57 & $8 \cdot 5$ & $19 \cdot 7$ & \\
\hline 25 & , & , & 3.55 & 6 & 40 & 62 & $7 \cdot 8$ & $15 \cdot 2$ & \\
\hline 26 & ", & ", & 4.10 & 11 & 38 & 61 & $7 \cdot 0$ & $14 \cdot 7$ & \\
\hline 27 & , & , & 4.25 & 3 & 32 & 62 & $6 \cdot 7$ & $14 \cdot 4$ & \\
\hline 28 & , & 22. î. 23 & 3.50 & Hall & - & 58 & $8 \cdot 8$ & $17 \cdot 0$ & \\
\hline 29 & ", & , & 4.10 & 13 & $2 \tilde{5}$ & 64 & $7 \cdot 8$ & $14 \cdot 5$ & $\begin{array}{l}\text { Wet kata } 15 \cdot 8 \\
\text { with children }\end{array}$ \\
\hline & & & & & & & & & waving arms \\
\hline 30 & & ," & 4.20 & 15 & 46 & 60 & $6 \cdot 4$ & $14 \cdot 2$ & \\
\hline 31 & $"$ & , & 4.30 & 7 & 36 & 62 & - & $11 \cdot 5$ & \\
\hline 32 & $"$ & 23. ii. 23 & 3.40 & Hall & 一 & 56 & $7 \cdot 3$ & $19 \cdot 5$ & $\begin{array}{l}\text { Dancing in pro- } \\
\text { gress. Wet kata } \\
\mathbf{1 7} \cdot 6 \text { with no } \\
\text { dancing }\end{array}$ \\
\hline
\end{tabular}


Table 2-(continued)

No. of
Exp.
(1)
33
34
.35
36
37

Time

No. of Temp. Dry Wet

(2)
B
",
"

Date

(4)

Room children ${ }^{\circ} \mathrm{Fahr}$

$\begin{array}{ccc}\text { Fahr. } & \text { kata } & \begin{array}{c}\text { kata } \\ (7)\end{array} \\ (8) & (9) \\ 63 & 6 \cdot 9 & 15 \cdot 4 \\ 65 & 7 \cdot 4 & 14 \cdot 0 \\ 58 & 6 \cdot 3 & 14 \cdot 1 \\ 60 & 7 \cdot 1 & 12 \cdot 4 \\ 60 & 6 \cdot 3 & 15 \cdot 0\end{array}$

Remarks

23. ii. 23

3.50 p.m.

(5) (6)

(10)

26. $\ddot{\text { ii. } 23}$

4.15

4.25

7

40
36

36
25

46

60

Wet bulb

therm. $54 \cdot 5^{\circ} \mathrm{F}$.

Dry bulb

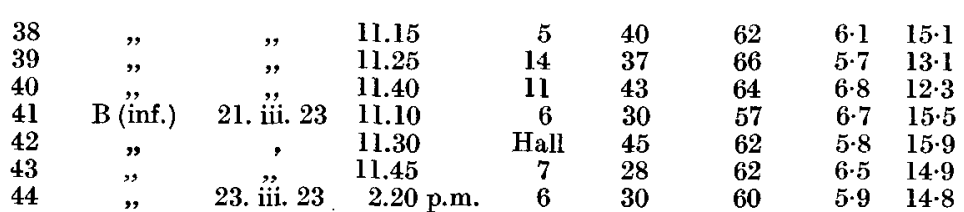

therm. $55^{\circ} \mathrm{F}$.

45

46
47

48

49

50

51

5.

53

54
55

56

57

58

59

60

61

62

63

64

65

66

67

68

69

70

71

72

73

74

75

76
77

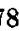

78

79

80

81
82

$$
\begin{gathered}
\text { ", } \\
\text { " } \\
\text { ", } \\
\text { "mixed) } \\
\text { ", } \\
\text { ", }
\end{gathered}
$$$$
\begin{array}{ll}
, & 2.35 \\
& 2.40
\end{array}
$$$$
2.50
$$$$
\text { " } \quad 3.0
$$$$
3.0
$$$$
3.10
$$$$
3.20
$$$$
3.25
$$$$
3.45
$$$$
\begin{array}{ll}
\text { " } & 3.45 \\
\text {, } & 3.55
\end{array}
$$$$
, \quad 4.5
$$

A (inf.)

2. iii.

4.15

"

,",

"

",

",

,

,"

,"

",

",

",

$"$

",

A (mixed)

,

,
" $\quad 2.45$
" 3.40
3.50

7. iii. $23 \quad 2.15$

, 2.45

" 3.0

, $\quad 3.10$

" 3.20

"․ 3.50

8. iii. $23 \quad 3.20$

13. iii. $23 \quad 11.25$ a.m.

14. iii. $23 \quad 2.45$ p.m.

, 2.50

" 3.0

$\begin{array}{ll} & 3.10 \\ " & 3.45 \\ " & 3.50 \\ " & 3.55\end{array}$$$
\begin{aligned}
& 1 \\
& 4 \\
& 5 \\
& 6
\end{aligned}
$$

7
1
2
4
7
6
1
13
15
16
10

29
37
34
42
28
40
8
26

52
47
39

64
65
63
63
64
66
66
59
66
66
64

59

66
66

66
64

64

66

66

66

59

61

66

65

62

62

68

$\overrightarrow{63}$

65

67

66

70

65

62

62

63

63

61

\begin{tabular}{|c|c|c|}
\hline " & " & 4.0 \\
\hline "? & $"$ & 4.10 \\
\hline A (inf.) & 16. iii. 23 & $\begin{array}{l}4.15 \\
11.55 \text { a.m. }\end{array}$ \\
\hline 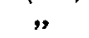 & 26. iii. 23 & 10.5 \\
\hline
\end{tabular}

$\begin{array}{rr}8 & 46 \\ 9 & 55 \\ 13 & 34 \\ 2 & 34 \\ 1 & 43\end{array}$

60

59

59

65

62
All windows throughout the school were closed on 23. iii. 23

$4 \cdot 6 \quad 13 \cdot 9$

$5 \cdot 2 \quad 14 \cdot 6$

$5 \cdot 5 \quad 16 \cdot 3$

$\begin{array}{ll}5 \cdot 5 & 15 \cdot 7\end{array}$

$5 \cdot 7 \quad 16 \cdot 8$

$5 \cdot 8 \quad 16 \cdot 1$

$5 \cdot 7 \quad 15 \cdot 7$

6.6 $16 \cdot 8$ Room 13 facing

$5 \cdot 8 \quad 15 \cdot 9$

$5 \cdot 8 \quad 15 \cdot 3$

$6.3 \quad 15.8$ Room 10 facing

$6 \cdot 1 \quad 15 \cdot 6$

$5 \cdot 6 \quad 14 \cdot 5 \quad$ Open fireplace

$6 \cdot 5 \quad 15 \cdot 7$

$5 \cdot 9 \quad 16 \cdot 6$

$8 \cdot 1 \quad 15 \cdot 7$

$6 \cdot 9 \quad 17 \cdot 2$

$\begin{array}{lll}5 \cdot 6 & 16 \cdot 3\end{array}$

$6 \cdot 9 \quad 17 \cdot 2$

$\begin{array}{ll}7 \cdot 3 & 16 \cdot 3\end{array}$

$6 \cdot 2 \quad 16 \cdot 3$

$6 \cdot 1 \quad 17 \cdot 3$

$6 \cdot 2 \quad 16 \cdot 0$

$6 \cdot 3 \quad 14 \cdot 5$

$8 \cdot 8 \quad 14 \cdot 5$

$4 \cdot 9 \quad 14 \cdot 1$

$\begin{array}{ll}6 \cdot 2 & 16 \cdot 7\end{array}$

$5 \cdot 8 \quad 16 \cdot 0$

$\mathbf{7 - 2} \quad 18 \cdot 1 \quad$ Room 7 facing

$7 \cdot 8 \quad 16 \cdot 9$

$6 \cdot 3 \quad 15 \cdot 5$

$6 \cdot 3 \quad 16 \cdot 7$

7.3 20.1 Teacher had just opened window. Said "Children were falling asleep"

8.2 18.0 Room 8 facing

$6 \cdot 3 \quad 16 \cdot 4$

$6 \cdot 4 \quad 16 \cdot 1$

$6 \cdot 3 \quad 15 \cdot 1$

$5 \cdot 8 \quad 16 \cdot 3$ prevailing wind 
Tabje 2-(continued)

\begin{tabular}{|c|c|c|c|c|c|c|c|c|c|}
\hline $\begin{array}{c}\text { No. of } \\
\text { Exp. } \\
(1)\end{array}$ & $\begin{array}{c}\text { School } \\
(2)\end{array}$ & $\begin{array}{c}\text { Date } \\
(3)\end{array}$ & $\begin{array}{c}\text { Time } \\
\text { (approx.) } \\
(4)\end{array}$ & $\begin{array}{c}\text { Room } \\
(5)\end{array}$ & $\begin{array}{l}\text { No. of } \\
\text { children } \\
(6)\end{array}$ & $\begin{array}{c}\text { Temp. } \\
\text { Fahr. } \\
\text { (7) }\end{array}$ & $\begin{array}{c}\text { Dry } \\
\text { kata } \\
(8)\end{array}$ & $\begin{array}{c}\text { Wet } \\
\text { kata } \\
(9)\end{array}$ & $\underset{(10)}{\text { Remarks }}$ \\
\hline 83 & A & 26. iii. 23 & 10.25 a.m. & 4 & 44 & 59 & $6 \cdot 7$ & $16 \cdot 2$ & \\
\hline 84 & , & , & 10.35 & $\overline{7}$ & 24 & 62 & $6 \cdot 7$ & $14 \cdot 4$ & \\
\hline 85 & ", & ", & 11.0 & Hall & 19 & 63 & $6 \cdot 3$ & $15 \cdot 7$ & \\
\hline 86 & & , & 11.25 & 2 & 35 & 62 & $6 \cdot 3$ & $16 \cdot 4$ & \\
\hline 87 & A (mixed) & ," & 11.35 & 1 & 40 & 63 & $5 \cdot 7$ & $15 \cdot 7$ & \\
\hline 88 & , & , & 11.35 & 8 & 55 & 60 & $6 \cdot 5$ & $16 \cdot 7$ & \\
\hline 89 & 3 & ," & 11.50 & 3 & 38 & 65 & $5 \cdot 2$ & $15 \cdot 8$ & \\
\hline 90 & A (inf.) & 27. iii. 23 & 2.20 p.m. & 1 & 43 & 66 & $4 \cdot \overline{5}$ & $15 \cdot 6$ & Open fire \\
\hline 91 & , & , & 2.35 & 2 & 36 & 64 & $4 \cdot 8$ & $16 \cdot 0$ & \\
\hline 92 & ", & $"$ & 2.40 & 5 & 47 & 64 & $5 \cdot 8$ & $15 \cdot 9$ & \\
\hline 93 & & , & 2.55 & 7 & 16 & 63 & $5 \cdot 7$ & $15 \cdot 2$ & \\
\hline 94 & $A$ (mixed) & $"$ & 3.5 & 1 & - & 68 & $5 \cdot 2$ & $14 \cdot 6$ & \\
\hline 95 & , & ," & 3.15 & 2 & 5 & 64 & $5 \cdot 3$ & $16 \cdot 7$ & \\
\hline 96 & ,. & , & 3.30 & 6 & 50 & 66 & $5 \cdot 6$ & $17 \cdot 1$ & \\
\hline 97 & „, & ," & 3.45 & 13 & 1 & 64 & $5 \cdot 6$ & $17 \cdot 1$ & \\
\hline 98 & $"$ & $"$ & 3.50 & 16 & 45 & 64 & $5 \cdot 7$ & $15 \cdot 9$ & \\
\hline
\end{tabular}

Table 3.

Velocity of air entering or leaving room by ducts.

\begin{tabular}{|c|c|c|c|c|c|c|c|c|c|c|}
\hline School & Date & Time & Room & $\begin{array}{l}\text { No. of } \\
\text { children }\end{array}$ & $\begin{array}{l}\text { Temp. } \\
\text { o Fahr. }\end{array}$ & \multicolumn{3}{|c|}{$\begin{array}{c}\text { Velooity } \\
\text { (metres per second) }\end{array}$} & $\begin{array}{l}\text { Dry } \\
\text { kata }\end{array}$ & $\begin{array}{l}\text { Wet } \\
\text { kata }\end{array}$ \\
\hline B & 26. ii. 23 & 11.0 a.m. & 3 & 40 & 60 & \multicolumn{3}{|c|}{0.951 (incoming air) } & $6 \cdot 3$ & $15 \cdot 0$ \\
\hline ," & , & 11.20 & 5 & 40 & 62 & \multicolumn{3}{|c|}{1.74 extraction shafts } & $6 \cdot 1$ & $15 \cdot 1$ \\
\hline & 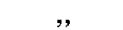 & 11.40 & 14 & 37 & 66 & $0 \cdot 423$ & & & $5 \cdot 7$ & $13 \cdot 1$ \\
\hline A & 2. iii. 23 & 2.30 p.m. & 1* & 39 & 66 & \multicolumn{3}{|c|}{$0 \cdot 303$ (incoming air) } & $5 \cdot 6$ & $14 \cdot 5$ \\
\hline , & ," & 2.45 & 2 & 37 & 66 & $1 \cdot 47$ & ", & , & $6 \cdot 5$ & $15 \cdot 7$ \\
\hline ,, & , & 3.30 & 5 & 45 & 66 & 0.56 & ,, & ," & $5 \cdot 9$ & $16 \cdot 6$ \\
\hline ," & , & 3.40 & 6 & 44 & 59 & $1 \cdot 85$ & ," & ," & $8 \cdot 1$ & $15 \cdot 7$ \\
\hline , & & 3.50 & 8 & 20 & 61 & $2 \cdot 68$ & , & , & $6 \cdot 9$ & $17 \cdot 2$ \\
\hline , & 7. iji. 23 & 2.15 & 1 & 40 & 66 & 0.203 & ", & ," & $5 \cdot 6$ & $16 \cdot 3$ \\
\hline , & , & 3.0 & 3 & 48 & 62 & 2.09 & , & , & $7 \cdot 3$ & $16 \cdot 3$ \\
\hline , & 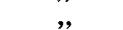 & 3.10 & 4 & 48 & 68 & 1.22 & , & ," & $6 \cdot 2$ & $16 \cdot 3$ \\
\hline , & 14. iii. 23 & 2.45 & 4 & 46 & 70 & 0.6 & ", & ", & $6 \cdot \overline{2}$ & $16 \cdot 7$ \\
\hline , & „, & 2.55 & 5 & 45 & 65 & $1 \cdot 47$ & , & , & $5 \cdot 8$ & $16 \cdot 0$ \\
\hline ," & ", & 3.5 & $7 \dagger$ & 42 & 62 & $1 \cdot 52$ & ," & ,, & $7 \cdot 2$ & $18 \cdot 1$ \\
\hline ," & ", & 3.15 & 1 & 26 & 62 & $1 \cdot 18$ & , & , & $7 \cdot 8$ & $16 \cdot 9$ \\
\hline
\end{tabular}

* Room 1 has an open fireplace in addition to shaft for incoming air.

$\dagger$ Facing a strong wind on that day.

The velocity of the air entering the rooms from the shafts appears to show no relationship to the kata readings taken in different parts of the room at the level of the children.

Table 4:

Number of organisms.

(Calculated as the number falling per square foot per minute.)

\begin{tabular}{|c|c|c|c|c|c|c|}
\hline School & Date & Time & Room & $\begin{array}{l}\text { No. of } \\
\text { children }\end{array}$ & Organisms & Remarks \\
\hline $\mathrm{B}$ & 27. ii. 23 & 3.50 p.m. & 15 & 46 & 37 & Hothaths \\
\hline ," & & 4.0 & 7 & 36 & 24 & \\
\hline , & 23. ii. 23 & 3.40 & Hall & $\begin{array}{c}\text { Drill class } \\
(30)\end{array}$ & 153 & Dancing and drill going on \\
\hline$\ddot{\mathbf{C}}$ & 27. ii. 23 & $\begin{array}{l}4.0 \\
4.0\end{array}$ & $\mathbf{5}$ & $\begin{array}{l}40 \\
40\end{array}$ & $\begin{array}{l}25 \\
23\end{array}$ & \\
\hline & 1. iii. 23 & 11.0 a.m. & $\mathrm{F}$ & 34 & 22 & \\
\hline Á & 7. iii. 23 & 3.0 p.m. & 3 & 48 & 19 & \\
\hline " & ", & 3.10 & 4 & 48 & 31 & \\
\hline & , & 3.40 & 6 & 44 & 31 & \\
\hline D & 19. iii. 23 & 11.0 a.m. & B & 24 & 38 & \\
\hline , & , & 11.0 & C & 22 & 31 & \\
\hline ", & ," & 11.10 & $\mathrm{D}$ & 35 & 29 & \\
\hline , & , & 11.20 & $\overline{\mathbf{A}}$ & 40 & 35 & \\
\hline ", & ," & 11.20 & $\mathrm{E}$ & 35 & 67 & $\begin{array}{l}\text { Change of class. Movement } \\
\text { during experiment }\end{array}$ \\
\hline , & $"$ & 11.30 & $\mathbf{E}$ & 44 & 24 & \\
\hline
\end{tabular}

Omitting the two experiments vitiated by movements, the average for Schools $\mathrm{C}$ and $\mathrm{D}$ is 29 and for Schools $A$ and B, 28. 